\title{
Regional Vegetation Database of Kiskunság
}

\author{
Tamás Rédei, Anikó Csecserits, György Kröel-Dulay
}

\begin{abstract}
The aim of the Regional Vegetation Database of Kiskunság (GIVD ID EU-HU-001) was to study the effect of different land-use on plant biodiversity. The Kiskunság region is a highly heterogeneous cultural landscape in central Hungary, with unique natural values, high diversity of land-use, its own well-defined environmental problems, and ongoing socio-economic changes, thus being an ideal setting for conducting integrative socio-ecological research and setting up an LTSER platform. In the past few years, we expanded the KISKUN LTER program into a broad-scale research framework or LTSER program by (1) covering all major landuse/habitat types occurring in the region; (2) reaching regional representativity by having multiple sites. Within the $7,500 \mathrm{~km}^{2} \mathrm{study}$ region, using a pre-defined algorithm we selected a network of 16 sites $(5 \times 5 \mathrm{~km})$ that covers the regional variability in land-use pattern, naturalness, and soil. We sampled three replicate stands (if available) of all major habitat types (arable land and vineyards, oldfields, natural grasslands and woodlands, forest plantations) in all 16 sites between 2006 and 2008. In a total of 604 plots (20 x 20 m) we detected the plant species present and estimated their cover.
\end{abstract}

Keywords: dry grassland; Hungary; land-use; sand vegetation.

GIVD Database ID: EU-HU-001

Last update: 2011-07-06

\section{Regional Vegetation Database of Kiskunság}

Scope: The aim of the database was to study the effect of different land-use on plant biodiversity.

Status: finished

Period: 2006-2008

Database manager(s): Tamás Rédei (redy@botanika.hu)

Owner: Institute for Ecology and Botany, HAS

Web address: [NA]

Availability: according to a specific agreement

Database format(s): Excel

Online upload: no

Online search: no

Publication: Rédei T., Kröel-Dulay Gy., Barabás S., Lellei-Kovács E., Szabó R., \& Török K. 2008. A network of long-term ecological and socioeconomic research sites to study the the effects of land use change. In: Kovács-Láng E., Molnár E., Kröel-Dulay Gy. \& Barabás S. (szerk.): The KISKUN LTER: Long term Ecological research in the Kiskunság, Hungary. Institute of Ecology and Botany, Vácrátót, pp. 15-19.

Plot type(s): normal plots Plot-size range: $400-400 \mathrm{~m}^{2}$

Non-overlapping plots: 605

Estimate of existing plots: 3,000

Total plot observations: 605

Completeness: $20 \%$

Countries: $\mathrm{HU}: 100.0 \%$

Forest: [NA] - Non-forest: [NA]

Guilds: all vascular plants: $100 \%$

Environmental data: altitude: $100 \%$; slope aspect: $100 \%$; slope inclination: $100 \%$; soil depth: $100 \%$; other soil attributes: $100 \%$

Performance measure(s): cover: $100 \%$

Geographic localisation: GPS coordinates (precision $25 \mathrm{~m}$ or less): $100 \%$

Sampling periods: $2000-2009: 100.0 \%$

Information as of 2012-07-12; further details and future updates available from http://www.givd.info/ID/EU-HU-001

Tamás Rédei (redy@botanika.hu), Melinda Halassy (halassy.melinda@okologia.mta.hu), Gábor Ónodi (onodi.gabor@okologia.mta.hu), Anikó Csecserits* (csecserits.aniko@ okologia.mta.hu), Katalin Szitár (szitar.katalin@okologia.mta.hu) György Kröel-Dulay (kroel-dulay.gyorgy@ okologia.mta.hu)

Plant Ecology, Institute for Ecology and Botany, HAS, Alkotmany 2-4., 2163 Vacratot, HUNGARY

*Corresponding author 